\title{
STRATEGI KOMUNIKASI YAYASAN MASJID BESAR AL-FALAH DALAM MENANAMKAN NILAI-NILAI KEISLAMAN KEPADA JAMA'AH
}

\author{
P-ISSN: 2085-4536 | E-ISSN: 2721-7183 \\ Link: https://jurnal- \\ stidnatsir.ac.id/index.php/dakwah/article/view/57 \\ DOI : https://doi.org/10.38214/jurnaldawahstidnatsir.v2i02.57 \\ Dikirim: 25-03-2019 \\ Direview: 05-04-2019 \\ Diterbitkan: 14-04-2019 \\ SAEFUL ROKHMAN \\ saeful@stidnatsir.ac.id \\ STID Mohammad Natsir - Indonesia \\ RISKA SITI AISYAH \\ riskasitiaisyah@stidnatsir.ac.id \\ STID Mohammad Natsir - Indonesia
}

\begin{abstract}
ABSTRAK
Tujuan Penelitian: Penelitian ini bertujuan untuk mengungkap strategi komunikasi Yayasan Masjid Besar Al-Falah dalam menanamkan nilai-nilai keislaman kepada jama'ah. Metode Penelitian: Kualitatif. Hasil Penelitian: Berdasarkan strategi komunikasi yang digunakan yaitu strategi kepatuhan, Masjid Al- falah menghadrikan para da'I yang memiliki daya tarik moral terhadap jama'ah serta memiliki kekuatan yang sangat kuat sehingga para jama'ah bisa mematuhi dan mengikuti kegiatan yang ada di masjid tersebut tanpa ada paksaan. Masjid al- falah memberikan penghargaan kepada jama'ah yaitu penghargaan secara umum yaitu fasilitas yang ada di masjid tersebut seperti ruangan yang nyaman serta menyediakan makanan dan minuman bagi para jama'ah yang hadir. Berdasarkan strategi Konstruktivisme, Masjid al- falah memberikan penghargaan kepada jama'ah yaitu penghargaan secara umum yaitu fasilitas yang ada di masjid tersebut seperti ruangan yang nyaman serta menyediakan makanan dan minuman bagi para jama'ah yang hadir. Berdasarkan strategi kesopanan masjid al-Falah Masjid al-Falah memberikan nasihat kepada jama'ah melalui kegiatan ta'lim dengan metode tanya jawab terhadap jama'ah.
\end{abstract}

Kata kunci: Strategi komunikasi, masjid, nilai keislaman, jama'ah

\section{PENDAHULUAN}

Masjid tidak luput dari berbagai problematika, baik menyangkut pengurus, kegiatan maupun berkenaan dengan jama'ah. Jika saja problematika itu dibiarkan secara terus menerus tanpa diperbaiki maka 
kemakmuran dan kemajuan masjid akan terhambat. Fungsi masjid menjadi tidak berjalan sebagaimana mestinya, sehingga keberadaan masjid tidak berbeda dengan bangunan biasanya. Berikut beberapa permasalahan yang dihadapi oleh ummat muslim akan keberadaan suatu masjid yang semakin hari semakin ditinggalkan oleh ummat Islam sendiri.

Pertama manajemen masjid yang tidak teratur, manajemen masjid adalah suatu proses atau usaha mencapai kemakmuran masjid yang ideal, dilakukan oleh seorang pemimpin pengurus masjid bersama staf dan jama'ahnya melalui berbagai aktivitas yang postif. Permasalahan yang dihadapi biasa timbul dari internal pengurus itu sendiri seperti adanya pengurus yang tertutup atau tidak aktif dalam ikut serta memakmurkan masjid sehingga kegiatan tidak berkembang bahkan tidak berjalan sama sekali. Hal ini disebabkan karena sifat pengurus yang tertutup dan tidak mau menerima saran dari jama'ah dan merasa bahwa hanya pengurus lah yang mengetahui semuanya sehingga saran dari jama'ah pun tidak diterima.

Kedua, jama'ah pasif juga salah satu faktor penghambat kemakmuran masjid. Pembangunan masjid tidak akan berjalan dengan lancar tanpa adanya keikutsertaan jam'ah, pada proses pembangunan misalnya sebagian jama'ah enggan untuk memberikan sedikit hartanya untuk kepentingan masjid atau jama'ahnya sendiri malas untuk mengikuti kegiatan atau kajian yang dilaksanakan di masjid tersebut. Dalam memajukan dan memakmurkan sebuah masjid perlu ada partisipasi dari jama'ah karena masjid merupakan sentral kegiatan ummat Islam, jika ummat Islam nya sendiri malas untuk pergi ke masjid maka cita-cita menjadikan masjid sebagai pusat pembinaan ummat tidak akan terlaksana dengan baik. Dinamika sebuah masjid akan terjadi apabila jama'ah aktif, mau peduli, mau berbagi, dan meringan langkahnya untuk pergi ke masjid.

Ketiga, minimnya kegiatan. Melihat realita yang ada kebanyakan masjid yang ada saat ini hanya di fungsikan untuk kegiatan ibadah wajib saja,tanpa kegiatan yang lain, sehingga keberadaan masjid semakin ditiadakan. Masjid hanya ramai dalam seminggu sekali ketika melaksanakan shalat jum'at atau ada kegiatan ta'lim saja. Ini keadaan yang sangat ironi, seharusnya masjid memiliki kegiatan yang dapat mencakup semua kalangan baik dari anak-anak, remaja, maupun orang dewasa.

Keempat, fasilitas tidak baik. Kurangnya pemeliharaan mengakibatkan masjid kotor dan rusak. Bila tempat mengambil air wudhu 
dan WC nya kurang dirawat dan dibersihkan, ini berdampak pada citra sebuah masjid. Banyak masjid yang mengabaikan akan kebersihan masjid ini sehingga aroma yang tidak sedappun mengganggu kenyamanan para jama'ah dalam beribadah dan citra masjid pun lama kelamaan akan menjadi negatif. Masjid tempat beribadah harus dijauhkan dari kesan kotor, karena sunnahnya ummat Islam untuk senantiasa menjaga kebersihan dan kenyamanan masjid tersebut.

Dalam kaitan persoalan tersebut, pemerintah mengakui bahwa peranan agama merupakan faktor penting dalam menciptakan warga Negara Indonesia yang berbudi luhur. Enam belas abad yang silam pertumbuhan masyarakat Islam yang digerakan oleh Nabi Muhammad terbagi kedalam dua kurun yaitu kurun Mekkah dan kurun Madinah. Berpangkal dari hubungan makhluk dengan sang kholiq (sang pencipta) dilanjutkan dengan hubungan sesama makhluk dalam bentuk kehidupan sosial bermasyarakat (Muamalab). Singkatnya selain menyempurnakan ajaran tauhid Nabi Muhammad shallalabu 'alaibi wa sallam juga membentuk masyarakat Islam yang diatur oleh syariat serta dijalin kukuh dengan akhlak mulia.

Organisasi sosial masyarakat yang dibangun oleh Nabi Muhammad shallalahu alaibi wa sallam semakin lama semakin berkembang hingga menjadi kekuatan tersendiri yang disegani. Sejarah mencatat bahwa kemenangan Islam di Madinah bukan karena persenjataan yang lengkap, bukan karena benteng yang kokoh tetapi karena masjid yang makmur. Bagi Nabi Muhammad shallalahu 'alaibi wa sallam bangunan benteng yang kokoh hanya sebagai pertahanan fisik, sedangkan masjid adalah pertahanan fisik mental artinya sekalipun fisik kuat jika tanpa diimbangi mental yang kuat, niscaya tidak akan mampu bertahan terhadap gempuran dan cobaaan Karena pertahanan mental adalah pertahanan pokok dan utama. Nabi menjadikan masjid sebagai tempat pembinaan masyarakat dengan sistem ibadah dan membina fisik mereka dengan sistem muamalah. Masjid adalah pusat pembinaan masyarakat dan pusat pembangunan budaya serta peradaban masyarakat.

Keberadaan masjid pada umumnya merupakan salah satu perwujudan aspirasi ummat Islam sebagai tempat ibadah yang menduduki fungsi sentral. Mengingat fungsiya yang sangat strategis, maka perlu dibina sebaik-baiknya baik dari segi fisik bangunan maupun segi kegiatan pemakmurannya. Masjid harus memerankan dirinya sebagai pusat kegiatan 
dan peribadatan masyarakat dalam arti luas termasuk kegiatan pembinaan ekonomi rakyat.

Semua permasalahan yang dihadapi akan segera diperbaiki apabila terjalinnya hubungan komunikasi secara baik antar jama'ah dan para pengurus masjid tersebut. Komunikasi hanya akan terjalin apabila keduanya saling memahami dan saling ada timbalbalik antar keduanya.

Komunikasi adalah suatu proses pertukaran informasi diantara individu melalui sistem, lambang-lambang, tanda-tanda atau tingkah laku. Komunikasi juga diartikan sebagai cara untuk mengkomunikasikan ide dengan pihak lain, baik dengan berbincang-bincang, berpidato,menulis maupun responden ${ }^{1}$. Sebagai salah satu sisi dalam kehidupan manusia, aktivitas komunikasi itu dikatakan akademisi sebagai aktivitas vital di kehidupan manusia. Cangara menyimpulkan bahwa penilaian dari banyak pakar bahwa komunikasi adalah sebagai suatu kebutuhan fundamental bagi seseorang dalam kehidupan bermasyarakat.

Tanpa adanya komunikasi tidak mungkin sebuah masyarakat akan terbentuk, sebaliknya tanpa masyarakat, manusia tidak mungkin mengembangkan komunikasi. Maka komunikasi ini penting bagi keberlangsungan dan keberhasilan suatu masyarakat. Di zaman yang modern dengan semakin canggihnya teknologi komunikasi, akan semakin memudahkan seseorang berkomunikasi satu dengan yang lain dan memperoleh suatu informasi dari berbagai belahan dunia. Namun disisi lain ada hal negatif apabila dalam komunikasi terjadi penyimpangan yang tidak sesuai dengan aturan yang berlaku, yang bisa menimbulkan kesenjangan sosial terhadap satu individu terhadap indvidu yang lain, satu kelompok terhadap kelompok lain bahkan dari satu bangsa ke bangsa lain. ${ }^{2}$

Orang yang tidak pernah berkomunikasi dengan manusia bisa dipastikan akan tersesat karena ia tidak sempat menata dirinya dalam suatu lingkungan sosial. Komunikasilah yang memungkinkan individu

${ }^{1}$ Dr. Harjani Hefni, Lc., M.A. Komunikasi Islam Prenada Media Group, Jakarta 2015 hal 2

${ }^{2}$ Fathimah Munawaroh Strategi Komunikasi Da'wah Yayasan Alkhansa dalam mengantisipasi Kristenisasi di wilayah BSD, Tanggerang Selatan, Skripsi, Jakarta STID Mohammad Natsir, hal 1 
membangun suatu kerangka rujukan dan menggunakannya sebagai panduan untuk menafsirkan situasi apapun yang ia hadapi. Komunikasi pula yang memungkinkannya mempelajari situasi problematik yang ia hadapi. Komunikasi pula yang memungkinkannya mempelajari dan menerapkan strategi adaptif untuk mengatasi situasi tersebut. ${ }^{3}$ Begitu pula dalam berda'wah seorang da'i harus bisa berkomunikasi dengan mad'unya sesuai kondisi yang ada di masyarakat. Karena komunikasi adalah salah satu alat yang penting untuk menjalin hubungan baik dengan masyarakat.

Kurangnya pemahaman pada masyarakat akan pentingnya komunikasi menyebabkan ketidak pedulian kepada sesama masyarakat yang membuat masyarakat tidak saling mengenal dan sibuk pada dunianya masing-masing. Karena dengan keadaan seperti ini menjadi peluang bagi musuh Islam untuk menghancurkan ummat Islam itu sendiri.

Pada saat ini banyak strategi yang digunakan ummat Islam dalam mensyiarkan agama Islam, yaitu salah satunya dengan adanya tempat beribadah yang mempunyai sarana-sarana dan kegiatan yang dapat menarik masyarakat muslim untuk mengikuti kegiatan tersebut yang nantinya akan membuka kesadaran ummat akan pentingnya agama Islam tersebut. Salah satu rukun dalam berda'wah adalah adanya washilatu da'wab ${ }^{4}$ yang digunakan untuk menyampaikan da'wah, salah satunya adalah adanya sebuah masjid sebagai tempat pergerakan akan keberhasilan da'wah. Rasulullah shallalahu 'alaibi wa sallam dalam melakukan perjalanan hijrahnya ke Madinah salah satu upaya untuk mempersatukan ummat Islam adalah dengan cara membangun atau mendirikan sebuah masjid, salah satu tujuannya adalah untuk digunakan sebagai tempat ibadah terutama untuk melaksanakan shalat lima waktu. ${ }^{5}$

Masjid adalah masalah yang pertama kali diperhatikan Rasulullah shallalahu alaibi wa sallam ketika sampai di Madinah. Ketika Rasulullah shallalahu 'alaibi wa sallam melakukan hijrah ke kota Madinah hal yang pertama kali yang dilakukan oleh Rasulullah adalah membangun sebuah

\footnotetext{
${ }^{3}$ Prof Deddy Mulyana, M.A.,Ph.D Ilmu Komunikasi, Bandung: PT Remaja Rosdakarya, Cet XVII, 2013, hal. 6

${ }^{4}$ Perantara da'wah yang berguna untuk memajukan keberhasilan da'wah
} 
Masjid lalu melaksanakan shalat di dalamnya yang diberi nama dengan Masjid Quba yang didirikan atas fondasi takwa setelah kenabian. ${ }^{6}$

Masjid mempunyai peran yang sangat besar dalam agama Islam. Sebagaimana yang disebutkan dalam hadist "Kondisi Seorang Hamba paling dekat dengan Rabbnya adalab ketika ia sedang sujud. Maka perbanyaklah berdo'a ketika sujud.' Kalau sujud merupakan lambang penyerahan diri kepada Allah, maka masjid adalah syiar kaum muslimin yang senantiasa mengesakan Allah ta'ala dan selalu bersujud kepada-Nya. ${ }^{8}$

Masjid merupakan lambang Islam. Jika tidak ada adzan tidak ada shalat, dan tidak ada shalat berjama'ah, berarti daerah itu tidak ada Islam dan tidak ada kaum muslim sebagaimana firman Allah ta'ala

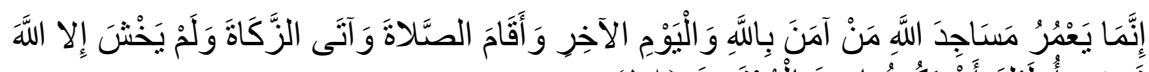

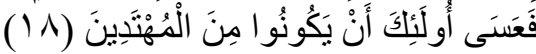

"Hanya yang memakmurkan masjid-masjid Allah ialah orang-orang yang beriman kepada Allah dan hari Kemudian, serta tetap mendirikan shalat, menunaikan zakat dan tidak takut (kepada siapapun) selain kepada Allah, Maka merekalah orang-orang yang diharapkan Termasuk golongan orang-orang yang mendapat petunjuk."(QS. At-taubah: 18)

Allah ta'ala berfirman

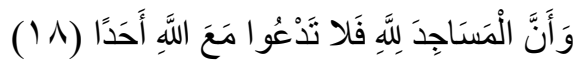

"Dan Sesunggubnya masjid-masjid itu adalah kepunyaan Allah. Maka janganlah kamu menyembah seseorangoun di dalamnya di samping (menyembah) Allah" (Qs. Jin: 18).

Masjid mempunyai fungsi yang lebih luas dari itu. Yakni masjid yang hidup, dan memancarkan kehidupan rumah tangga, masjid yang membersihkan jiwa ummat dari segala bentuk syirik dan kburafat, masjid yang menggerakan potensi kekuatan lahir dan bathin. Jelas pula khalifah Abu Bakar, yang mengikuti jejak risalah menegaskan dengan jangkauan

${ }^{6}$ Syaikh Syaifurrahman Al-Mubarakfuri, Ar-rahiq Al-Makhtum. Ummul Qura: Kelapa Dua Wetan-Ciracas-Jakarta Timur 2012, Cet ke-III, hal. 328.

${ }^{8}$ Ibid., hal. XVIII 
pandangan yang jauh. Fungsi masjid sebagai pusat reintegrasi ummat, bila kehidupan ummat masyarakat dilanda krisis. ${ }^{9}$ Dalam Salah satu Khutbahnya

"Dan Sesungguhnya kamu sekarang sedang di atas pengakuan khalifah ke Nabian (Tetapi kamu berada dalam persimpangan jalan). Nanti sudahku kamu akan melihat suatu pemerintahan yang kejam, raja yang keras kepala,ummat yang berpecah belah, darah tanpa lindungan hukum, mudah tertumpah. Jika sekiranya datang cengkraman dari pihak bathil dan timbul perlawanan dari pihak hak, perlawanan yang tidak meninggalkan bekas dan hancur lantarannya kebajikan, maka dikala itu, di masjidlah kamu menetap dan dari Al-Qur'an lah kamu mencari petunjuk. "

Misbach Malim dan Avid Shalihin mengutip sebuah perkataan dalam bukunya "Dinamika dan Strategi Da'wah" mengutarakan bahwa ada tiga pilar sekurang-kurangnya yang menjadi pusat pembinaan dan pusat kekuatann ummat yang satu sama lain tidak dapat dipisahkan yaitu masjid, Pesantren dan Kampus. Masjid tempat berkumpul masyarakat banyak, pesantren tempat berkumpul dan terbinanya para santri dan ulama, sedangkan kampus tempat berkumpul dan terbinanya para cendikiawan. Tiga kekuatan ini adalah unsur-unsur penting sebagai aset ummat yang perlu mendapat pembinaan yang sama dan seimbang dalam menggalang kesatuan, kekuatan dan keutuhan ummat secara menyeluruh. ${ }^{11}$

Di era modern ini penurunan nilai-nilai keislaman sedang terjadi di masyarakat bahkan melebihi apa yang terjadi pada zaman jahiliyah, realita yang terjadi saat ini adalah, perbuatan-perbuatan amoral manusia sekarang jauh melebihi perbuatan amoral pada zaman jahiliyyah sehingga disebut jahiliyyah modern. Oleh karena itu harus ada washilab untuk mengembalikan kesadaran ummat akan pentingnya nilai-nilai keislaman bagi kehidupan seorang muslim sebelum sesuatu yang buruk terjadi di negeri ini. Naudzubillah.

Dari jumlah masjid yang banyak ini terjadi penyempitan fungsi masjid. Masjid hanya difungsikan sebagai tempat sujud, tempat ibadah

\footnotetext{
${ }^{9}$ M.Natsir, Fihud Da'wah hal 98

${ }^{10}$ Ibid.,

${ }^{11}$ M. Yasir, Skripsi Perananan Masjid Baiturrahman dalam Pembinaan
}

Ummat, Strata 1 Sekolah Tingggi Ilmu Da'wah Mohammad Natsir Hal 4, tahun 2011 
mahdhah saja, seperti shalat, zikir,dan I'tikaf. Kurang berfungsinya masjid secara maksimal diantaranya disebabkan oleh rendahnya pengetahuan dan pemahaman masyarakat tentang masjid. Selain itu perhatian manusia masih terfokus pada usaha pengadaan sarana fisik. padahal, pemenuhan kebutuhan non fisik untuk memakmurkan masjid seperti yang diperintahkan Allah ta'ala dalam Al-Qur'an. Mengingat telah bergesernya peran dan fungsi masjid baik pada tingkat intensifikasi maupun elestensidikasi pada gilirannya dapat bermanfaat bagi pembinaan masyarakat. Kehadiran sebuah masjid di tengah kehidupan masyarakat dapat memberi inspirasi sosial yang tidak sederhana, misalnya pertemuan ummat muslim yang dilakukan setiap kali melaksanakan shalat dapat membangun kedekatan sosial untuk saling menumbuhkan semangat solidaritas yang sangat tinggi. Dalam kondisi apapun idealnya masjid dapat dijadikan sebagai pusat kegiatan masyarakat untuk berusaha mewujudkan tatanan sosial yang lebih baik.

Proses penanaman nilai-nilai keislaman kepada masyarakat merupakan sebuah upaya yang dilakukan kepada masyarakat guna membangun kesadaran dan pemahaman masyarakat terhadap Islam dan mampu mengaplikasikannya dalam kehidupan sehari-sehari melalui kegiatan-kegiatan seperti pembinaan masyarakat, kajian-kajian rutin yang dilakukan setiap hari, diskusi antar jama'ah yang membuka kesadaran ummat akan pentingnya wawasan keislaman.

Salah satu cara yang bisa digunakan dalam proses penanaman nilainilai keislaman pada masyarakat adalah dengan adanya masjid yang berperan sebagai pusat pembinaan ummat yang didalamnya diajarkan dan diterapakan nilai-nilai keislaman baik itu melalui pengajian,musyawarah dan lain sebagainya.

Semakin jauh ummat dari masjid, maka semakin hancurlah masa depan Islam. Ummat islam saat ini telah terkontaminasi dengan budayabudaya luar yang membuat mereka jauh dari masjid. Selain itu ummat Islam berbaur dengan berbagai kelompok yang saling bertentangan sehingga menumbuhkan bangunan Ukhuwah Islamiyyah. Namun tidak ada kata terlambat untuk memperbaiki keadaan ini. Penanaman nilai-nilai keislaman ummat melalui masjid adalah salah satu cara yang tepat untuk membentengi dan mengatasi masalah tersebut. 
Diantara masjid yang menjadi sentral pembinaan ummat dengan menanamkan nilai-nilai keislaman kepada ummat muslim adalah Yayasan Masjid Besar al-Falah. Masjid yang di resmikan pada tahun 1997 oleh Gubernur DKI yaitu Bapak Surjadi Soedirja, masjid ini milik pemerintah daerah Jakarata dengan luas lahan $5.000 \mathrm{~m} 2 .{ }^{12}$ Masjid ini terletak di jalan bambu Apus raya No 55, RT 1/RW4 Ceger, Cipayung-Jakarta Timur memiliki peranan khusus bagi kemajuan ummat. Bermula pendirian masjid ini atas dasar rasa prihatin warga sekitar karena di daerah Bambu Apus belum terdapat masjid dan tidak adanya aktivitas ummat Islam dalam melaksanakan ibadah di tempat tersebut, maka didirikanlah sebuah masjid diatas tanah milik pemerintah daerah.

Seiring berjalannya waktu masjid ini mengalami perkembangan yang sangat pesat. Masjid ini awalya seperti masjid-masjid yang ada di sekitarnya digunakan hanya untuk melakukan ibadah shalat, dzikir dan I'tikaf seperti pada umumnya saja dan tidak begitu dikenal oleh masyarakat dan jama'ahnya pun cenderung sedikit meskipun masjid ini berada di sentral masyarakat, akan tetapi seiring dengan berjalannya waktu masjid ini menjadi salah satu masjid favorit bagi jama'ah untuk menghadiri kajiankajian ilmu agama bahkan jama'ah yang hadir pun bisa sampai 1800 jama'ah. Keunggulan yang dimiliki masjid ini adalah strategi yang dilakukan dalam upaya menyebarkan syiar Islam tidak hanya dilaksanakan secara offline saja atau kegiatan ta'lim hanya bisa disaksikan oleh jama'ah yang hadir di masjid tersebut saja akan tetapi juga mengggunakan sistem online yaitu masjid ini memiliki media online seperti intsagram yang sampai saat ini sudah 5 ribu orang yang mengikuti akun tersebut, whatsapp dan youtobe guna menunjang keberhasilan da'wah masjid tersebut. Masjid alFalah ini memiliki 10 grup whatsaap yang terdiri dari 4 grup ikhwan dan 6 grup akhwat, grup whatsapp ini bertujuan untuk menshare kegiatan yang akan dilaksanakan di masjid tersebut guna memudahkan jama'ah untuk mengetahui informasi tersebut. Pada akun youtobenya sudah sekitar 4,9 Ribu pengunjung yang mengakses video kajian yang dilaksanakan di masjid tersebut . Chanel youtobe tersebut berisi kajian-kajian yang disiarkan secara langsung oleh pengurus masjid tersebut agar jama'ah yang tidak bisa hadir

\footnotetext{
${ }^{12}$ Wawancara dengan DKM Masjid Alfalah Ir. Haiban Hadjied. 29 Januari 2019
} 
ke masjid tersebut bisa juga mengikuti kajian tersebut tanpa harus berada di masjid tersebut. ${ }^{13}$

Keunggulan berikutnya yang dimiliki masjid tersebut adalah kajiankajian yang dilakukan setiap hari bahkan satu hari ada tiga kalian kegiatan ta'lim yang dilakukan diantara kegiatan ta'lim tersebut adalah Ngopi (ngobrol perkara iman) yaitu ta'lim yang dilakukan selepas melaksanakan shalat shubuh, kajian Dhuba yaitu ta'lim yang dilakukan pada waktu dhuha sekitar jam 08.00-10.30 WIB yang biasa diisi oleh ustad-ustad yang masyhur atau terkenal baik di media sosial maupun di kehidupan nyata, Kajian ba'da maghrib yaitu kegiatan ta'lim yang dilakukan setelah melaksanakan shalat maghrib. Hal ini menjadi kesempatan terbesar bagi jama'ah yang ingin mendalami pengetahuan-pengetahuan Islam secara mendalam. Dan ini juga menjadi strategi yang digunakan pengurus masjid guna menanamkan nilai-nilai keislaman pada jama’ah.

Keunggulan yang ketiga adalah masjid al-Falah ini juga memiliki wadah untuk para remaja guna membantu para remaja untuk menambah wawasan nilai-nilai keislaman dan mengasah kemampuan remaja dalam menjalankan roda keberhasilan da'wah. Remaja masjid ini dinamakan dengan RISMAF (Remaja Islam Masjid Alfalah) dan para remaja masjid pun banyak andil dalam kegiatan yang ada di Masjid al- Falah tersebut. Keunggulan yang keempat adalah masjid ini memiliki jaringan yang luas sehingga informasi seputar kegiatan dapat diakses oleh semua orang. Keunggulan yang kelima adalah masjid ini mampu menghadirkan muballigh yang mampu menarik perhatian jama'ah untuk menghadiri kajian tersebut dan dilaksanakan rutin setiap minggunya. Keunggulan inilah yang membuat masjid menjadi makmur dan banyak di kunjungi oleh jama'ah guna menambah wawasan nilai-nilai keislaman tidak hanya digunakan untuk ibadah sholat saja akan tetapi juga digunakan untuk kegiatan sosial lainnya musyawarah, silaturahim. Semua ini dilakukan dengan dasar proses komunikasi yang dilakukan oleh masjid tersebut sehingga masjid tersebut bisa makmur dan menjadi sentral ummat.

Melihat betapa pentingnya peran masjid dalam menyiarkan Islam dan menjadi salah satu strategi yang digunakan oleh pengurus masjid tersebut guna menunjang keberhasilan da'wah dan membina ummat

${ }^{13}$ Nur hasanah, Admin Pengelola media sosial masjid Al-Falah, wawanacara, 29 januari 2019 
dengan akidah dan nilai-nilai Islam. Maka penulis akan melakukan studi penelitian mengenai masjid tersebut dengan judul "Strategi Komunikasi Yayasan Masjid Besar Al- alah dalam Menanamkan Nilai-nilai Keislaman kepada Jama'ah ". Penelitian ini dilakukan sebagai bahan evaluasi akan keberhasilan da'wah kedepannya khusunya dalam fungsi masjid sebagai pusat pembinaan ummat.

Obyek penelitian ini adalah Yayasan Masjid Besar al- Falah termasuk yang ada di dalamnya pengurus dan pengelola yayasan masjid serta jama'ah tersebut sebagai subyek penelitian atau informan penelitian yang akan melengkapi data-data penelitian yang akan dilakukan. Informan penelitian merupakan subjek yang memahami informasi objek penelitian sebagai pelaku maupun orang lain yang memahami objek penelitian. ${ }^{14}$ lakukan

berikut ada daftar narasumber dari obyek penelitian yang penulis

\begin{tabular}{|l|l|l|}
\hline No & \multicolumn{1}{|c|}{ Nama Narasumber } & \multicolumn{1}{|c|}{ Jabatan } \\
\hline 1. & Haiban Hadji & $\begin{array}{l}\text { Ketua Yayasan Masjid Besar Al- } \\
\text { falah }\end{array}$ \\
\hline 2. & Nur Hasanah & $\begin{array}{l}\text { Pengelola Media Sosial Yayasan } \\
\text { Masjid Besar Al-Falah }\end{array}$ \\
\hline 3. & Eko & $\begin{array}{l}\text { Kepala Bidang Usaha Yayasan } \\
\text { Masjid } \\
\text { Besar Al-Falah }\end{array}$ \\
\hline 4. & Sri Rejeki Hartati & Jama'ah Remaja Masjid Al- falah \\
\hline 5. & Linda & Jama'ah Remaja Masjid Al- falah \\
\hline 6. & Nabilah Rahayu & Jama'ah masjid Al- falah \\
\hline 7. & Sri Gustiati & Jama'ah masjid Al- falah \\
\hline
\end{tabular}

${ }^{14}$ Burhan Bungin,Peneltian Kualitatif, Jakarta: PT Kharisma Putra Utama, Cet ke-9, 2017, Hal.78 
Sedangkan dalam penelitian kualitatif teknik sampling atau teknik pengambilam sampel yang sering digunakan adalah purposive sampling dan snowball sampling. Pada penelitian ini penulis menggunakan teknik pengambilan sampel dengan purposive sampling yaitu pengambilan sampel sumber data yang didasarkan dengan pertimbangann tertentu. Pertimbangan tertentu ini, misalnya orang tersebut yang dianggap paling tahu tentang apa yang kita harapkan atau mungkin dia sebagai penguasa sehingga akan memudahkan peneliti menjelajahi situasai yang akan diteliti. ${ }^{15}$

Pendekatan yang digunakan dalam penelitian ini adalah pendekatan deskriptif kualitatif sehingga menitik beratkan pada wawancara mendalam yang merupakan langakah untuk mendapatkan informasi tentang strategi komunikasi yang dilakukan Yayasan Masjid Besar al- Falah dalam menanamkan nilai-nilai keislaman kepada jama'ah dan mengubah presepsi masyarakat akan fungsi masjid yang sesungguhnya.

Adapun analisis data yang penulis gunakan adalah analisis data model Miles dan Hubermen(1984) aktivitas dalam analisis kualitatif dilakukan scara interaktif dan berlangsung secara terus menerus sampai tuntas, sehingga datanya sudah jenuh. Aktivitas analisis data yaitu terbagai menjadi tiga tahap. ${ }^{16}$

\section{HASIL DAN DISKUSI}

\section{Strategi Mendapatkan Kepatuhan}

\section{Komitmen Impersonal (ketertarikan daya moral)}

Dalam ilmu komunikasi seorang da'i adalah komunikator yaitu orang yang menyampaikan pesan komunikasi kepada orang lain. Secara ideal, seorang da'i adalah orang mukmin yang menjadikan Islam sebagai agamanya, al-Qur'an sebagai pedomannya, Nabi Muhammad Rasulullah shallalahu 'alibi wa sallam sebagai pemimpin dan teladan baginya ia benarbenar mengamalkannya dalam tingkah laku dan perjalanan hidupnya, kemudian ia menyampaikan Islam yang meliputi aqidah, syariah, dan akhlak

\footnotetext{
${ }^{15}$ Sugiyono, Metode Penelitian Manajemen, hal. 368

${ }^{16}$ Ibid., Hal 91
} 
kepada seluruh manusia. Seorang da'i harus memiliki qudwah yang baik karena pada hakikatnya setiap apa yang ada pada diri seorang da'i adalah bernilai da'wah baik dalam perkataan, tingkah laku dan akhlaknya yang kelak akan dicontoh oleh mad'unya. ${ }^{17}$

Masjid al- Falah dalam hal ini menghadirkan para da'i yang kompeten yang dalam artian memiliki aqidah yang lurus, beriman, dan bisa menjadi qudwah bagi para mad'u serta memiliki ilmu yang luas dan mendalam. Hal ini bisa menjadi daya tarik tersendiri untuk seorang mad'u atau jama'ah untuk hadir di masjid tersebut. Dalam hal ini masjid al-Falah selaaras dengan teori strategi kepatuhan dalam menanamkan nilai-nilai keislaman kepada jama'ah yaitu dengan menggunakan komitmen impersonal yaitu memiliki daya tarik moral sehingga apabila seorang da'i memiliki daya tarik yang besar maka pesan yang disampaikan kepada jam'ah akan diterima secara baik. Sehingga ketika seorang da'i memberikan nasihat maka secara tidak langsung seorang mad'u akan mematuhi dan menerima nasihat tersebut.

Da’i yang dihadirkan merupakan da'i yang memiliki daya tarik tersendiri dihati para jama'ah yang sudah memiliki keahlian tersendiri dalam bidangnya masing-masing seperti dalam hal fiqih, akidah, tafsir, parenting, dan lain sebagainya. Setelah itu dibuat pamflet yang disebar melalui media sosial seperti instagram, whattsapp, sehingga informasi tersebut bisa diakses lebih luas oleh para jama'ah. Lalu kegiatan ta'lim pun disiarkan secara langsung di media sosial seperti youtobe, hal ini bertujuan agar para jam'ah yang tidak bisa hadir ke masjid tetap bisa mengikuti kegiatan ta'lim. Adapun Para da'i yang dihadirkan di masjid tersebut antara lain $^{18}$

1. Ust. Dr. Syafiq Riza Basalamah, MA

2. Ust. Subhan Bawazier

3. Ust. Dr. Khalid Basalamah

4. Ust. Dr. Amir Faishol Fath, MA.

\footnotetext{
Maret 2019

${ }^{18}$ www.Instagram//@alfalahbambuapus
}

${ }^{17}$ Haiban Hadji, wawancara, Ketua Yayasan Masjid Besar Al-Falah,07 
5. Ust. Oemar Mita, Lc

6. Ust. Farid Ahmad Okbah, MA.

7. Ust. Firanda Andirdja, MA.

8. Ust. Budi Ashari, Lc

9. Ust. Wijayanto

10. Ust. Ahmad Sarwat, Lc.

11. Ust. Asep Sobari Lc.

12. Ust. Najmi Umar Bakkar

13. Ust. Bendri Jaysurrahman

14. Ust Adin Husaini

15. Ustadzah Irene Handoko

16. Ust. Ahmad Ridwan, Lc

17. Ust. Sudarmoko

18. K.H Anwar Sanusi

19. Ust. Herfi Ghulam Faizi, Lc.

20. Kak Dwi Kanvas

Para da'i tersebut memiliki daya tarik moral tersendiri bagi para jama'ah, serta memiliki keahlian dibidang masing-masing. Cara penyampaian para da'i pun sangat komunikatif sekali sehingga mudah dipahami dan diterima oleh para jam'ah ${ }^{19}$

Pengurus masjid tidak perlu menghadirkan jama'ah secara paksa karena jama'ah akan hadir dengan sendirinya bahkan berbondongbondong untuk mengikuti kegiatan da'wah tersebut, hal ini disebabkan karena masjid al- Falah menghadirkan para da'i yang sudah memiliki daya tarik moral sendiri pada jama'ah. Karena teori kepatuhan ini akan berhasil apabila kekuasaan yang ada pada diri seorang da'i besar kemudian memilih taktik atau cara yang digunakan untuk menggunakan kekuasaan itu. Strategi

${ }^{19}$ Nabilah Rahayu, jama'ah Masjid al-Falah, Wawancara 4 mei 2019 
ini digunakan oleh masjid al- Falah untuk melaksanakan keberlangsungan da'wah sampai saat ini.

\section{Pemberian Penghargaan}

Pemberian penghargaan yang diberikan masjid al- Falah kepada jama'ah adalah pemberiaan penghargaan secara umum seperti Fasilitas yang baik dan nyaman yang disediakan di masjid al- Falah. Hal ini memberikan nilai positif terhadap masjid tersebut, karena dengan adanya fasilitas yang nyaman, maka jama'ah akan sesantiasa betah untuk melaksanakan ibadah di tempat tersebut. Memberikan penghargaan terhadap kepatuhan yang telah dilaksanakan oleh para jama'ah. Salah satu jama'ah masjid al-Falah mengungkapkan bahwa fasilitas yang diberikan oleh masjid al-Falah sangat cukup dan sangat nyaman sekali ketika jama'ah hadir di masjid tersebut. ${ }^{20}$

Salah satu bentuk kepatuhan yang ditunjukkan oleh jama'ah yaitu para jam'ah secara sadar mematuhi apa yang telah di instruksikan oleh para pengurus masjid ketika menghadiri kajian yang ada di masjid tersebut, dan menghadiri kajian tersebut tanpa paksaan dari pihak manapun maka dari itu masjid al- Falah ini memberikan penghargaan kepada para jam'ah atas kepatuhan tersebut, penghargaan yang diberikan masjid al- Falah adalah berupa fasilitas-fasilitas yang disediakan seperti makanan dan minuman gratis bagi jama'ah yang hadir, juga ruangan yang nyaman bagi para jama'ah, meskipun ini hal yang lumrah bagi sebagian masjid lain. Masjid ini mengguanakan strategi kepatuhan untuk melangsungkan keberhasilan da'wahnya. Masjid al-Falah juga menyediakan makanan dan minuman bagi para jama'ah, dan selalu menyediakan makanan dan minuman untuk buka puasa untuk jama'ah yang senantiasa melakukan puasa sunnah senin dan kamis, Serta menyediakan juga makanan untuk berbuka puasa wajib seperti bulan ramadhan. masjid ini juga memberi peluang kepada jama'ah yang lain untuk berbagi kepada jama'ah lain khususnya ketika hari jum'at. Makanan yang ada di masjid al-falah bersumber dari para mubsinin yang ingin bersadaqah kepada jama'ah yang lain,para muhsinin datang kw masjid secara langsung untuk memberikan shadaqah tersebut baik berupa makanan atau minuman, lalu pengelola masjid yang membagikannya

${ }^{20}$ Sri Gustiati, jama'ah masjid al-falah, wawancara, Jakarta 5 Mei 2019 
kepada para jama'ah dan sampai saat ini ada sekitar 200 paket makanan yang selalu ada di masjid al-falah untuk para jama'ah dan pengurus masjid ${ }^{21}$.

Semua yang disediakan oleh pihak masjid semata-mata untuk memberikan bentuk apresiasi pengurus kepada jama'ah karena telah berpartisipasi mengikuti kegiatan yang ada di masjid tersebut, juga membantu para jam'ah agar tidak perlu repot keluar untuk membeli makanan dan hal lain sebagainya. Strategi ini digunakan oleh masjid alFalah guna menunjang keberhasilan da'wah. ${ }^{22}$

Penghargaan inilah yang diberikan masjid al-Falah kepada para jama'ah agar jama'ah senantiasa nyaman dan tenang untuk melaksanakan ibadah, apabila jama'ah sudah merasa nyaman dengan fasilitias yang ada maka jama'ah akan menjadikan masjid tersebut sebagai tempat favorit untuk melaksanakan ibadah dan juga bisa menambah semangat para jama'ah dalam mengikuti kegiatan ta'lim yang ada di masjid tersebut.

\section{Keahlian (Menunjukan pengetahuan untuk penghargaan)}

Pengetahuan yang dimiliki seorang da'i mampu mempengaruhi jama'ah yang hadir dan mengikuti kegiatan ta'lim yang ada di masjid tersebut, apabila seorang da'i yang hadir tidak mampu menyampaikan materi dengan jelas atau tidak mendalam, maka akan menimbulkan kebingungan kepada para jama'ah sehingga pesan yang disampaikan tidak tersalurkan dengan benar.

Menurut jama'ah yang hadir di masjid tersebut penyampaian para da'i dalam mengisi kegiatan ta'lim sangat komunikatif dan mudah di mengerti oleh para jam'ah. Sebagai contoh adalah ta'lim yang diisi oleh ustad Subhan Bawazier beliau menyampikan pesan da'wah dengan gaya dan cara khas beliau dengan kalimat yang mudah difahami, pengetahuan ustad Subhan terhadap suatu materi yag disampaikan mampu memberikan pemahaman kepada jama'ah sehingga jama'ah memberikan penghargaan kepada ustad tersebut, tentunya bukan penghargaan yang bersifat fisik akan

\footnotetext{
Maret 2019

${ }^{22}$ Haiban Hadji, Ketua Yayasan Masjid Besar Al-Falah, wawancara, Jakarta 7 Maret 2019
}

${ }^{21}$ Haiban Hadji, wawancara, Ketua Yayasan Masjid Besar Al-Falah,07 
tetapi penghargaan berupa pemahaman jam'ah terhadap pesan ustad Subhan yang disampaikan berupa peningkatan amal ibadah pada diri jama'ah. ${ }^{23}$

\section{Strategi Konstruktivisme}

Masjid al- Falah membuka peluang yang sangat besar kepada jam'ah untuk senantiasa menghadiri kajian-kajian ilmu tanpa mengeluarkan biaya sedikitpun, bahkan semua ormas (organisasi masyarakat) pun bisa menghadiri kajian tersebut tanpa membedakan suku, ras dan budaya. Masjid ini merangkul siapa saja yang ingin belajar dan mendalami wawasan keislaman, tanpa ada paksaan dari siapapun. Masjid ini menjadi tempat redutaimen yaitu masjid sebagai tempat rekreasi, edukasi dan entertaimen (hiburan). Masjid al- Falah ini bisa menjadi tempat hiburan sekaligus pendalaman wawasan-wawasan ilmiah. Setiap jam'ah yang akan hadir ke masjid tersebut bisa membawa seluruh keluarganya untuk mengikuti kegiatan yang ada di masjid tersebut. ${ }^{24}$

Tujuan dilakukannya kegiatan keagamaan yang berbasis masjid adalah agar senantiasa masyarakat dekat dengan masjid dan menjadikan masjid sebagai tempat pembinaan ummat serta menjadikan masjid sebagai sentral kegiatan keagamaan ummat Islam di daerah tersebut, sehingga pemahaman masyarakat akan terbuka akan pentingnya masjid sebagai tempat pembinaan ummat.

Melakukan kegiatan melalui masjid dan menyediakan berbagai kegiatan untuk memperoleh beberapa tujuan merupakan strategi konstruktivisme da'wah yang dilakukan oleh masjid al- Falah tersebut. Di dalam masjid seluruh jama'ah dikumpulkan dan diberikan materi pembelajaran wawasan keislaman seperti materi aqidah, fiqih, dan materi lainnya yang dapat meningkatkan ketaqwaan jama'ah pada Allah ta'ala.

Jama'ah yang hadir di masjid tersebut tidak hanya datang dari satu daerah saja akan tetapi dari berbagai daerah, namun tujuan jama'ah yang hadir sama-sama untuk mengikuti kajian ilmu dan menerima ilmu dari para da’i yang mengisi kajian di masjid tersebut. Secara keseluruhan masjid ini

\footnotetext{
${ }^{23}$ Jama'ah masjid al-falah, wawancara, Jakarta 5 Mei 2019

${ }^{24}$ Haiban Hadji, Wawancara, Ketua Yayasan Masjid besar Al-Falah, 07 maret 2019
} 
sudah menerapkan sunnah-sunnah Rasulullah shallalabu 'alaibi wa sallam artinya seluruh praktik ibadah sudah sesuai dengan apa yang telah di contohkan oleh Rasulullah shallalahu 'alaibi wa sallam

Serta begitupula dengan para da'i yang dihadirkan sudah mengikuti ajaran sesuai apa yang diajarkan oleh Rasulullah. Masjid ini mengajak para jama'ah untuk senantiasa kembali kepada ajaran yang telah dibawa oleh Rasulullah shallalahu 'alaibi wa sallam meninggalkan perkara-perkara yang bid'ah serta melakukan ibadah secara sunnah, masjid ini pula memberikan pemahaman kepada jama'ah untuk meninggalkan budaya nenek moyang yang memang pada dasar tidak ada dalil yang menyebutkan. Penyampaian pemahaman ini kepada jama'ah dilaksanakan melalui fase-fase kegiatan yang ada di masjid tersebut agar para jam'ah lebih memahami mengenai ajaran Islam yang benar. Salah satu fase kegiatannya yaitu dengan melalui kajian-kajian yang membahas seputar aqidah, dan memang ada satu khusus yang kajian yang di dalamnya membahas tentang aqidah dan ketauhidan. Dari kegiatan kajian inilah jama'ah sedikit demi sedikit akan memahami apa yang disampaikan oleh para da'i. Kajian dengan tema tauhid yang dilakukan secara berkesinambungan membuat para jama'ah memahami arti aqidah yang sebenarnya.

Masjid al-Falah dalam melangsungkan keberhasilan da'wahnya melalui pemahaman konstruksi pribadi, karena setiap individu yang hadir pada kegiatan di masjid tersebut berbeda-beda dan memiliki latar belakang yang berbeda pula baik dari NU (nabdhatul 'ulama), Muhammadiyah, Persis, maupun Salafi. Meskipun dari latar belakang yang berbeda akan tetapi masjid al- Falah ini memberi peluang kepada siapa saja dan dari kalangan mana saja untuk hadir di masjid tersebut dengan satu alasan karena mencari ilmu. Setiap individu memiliki perbedaan dalam hal memandang orang lain. Maka dalam hal menyikapi perbedaan ini masjid al- Falah memberikan wadah untuk jama'ah untuk senantiasa meneriman jama'ah yang lain yang nantinya akan diajak dan diarahkan kepada pemahaman yang satu yaitu bertauhid kepada Allah serta melaksanakan dan mengikuti apa yang telah dibawa oleh Rasulullah shallalabu 'alaibi wa sallam. Karena hanya aqidah yang shobih yang dapat menyelamatkan manusia kelak di hari kiamat nanti. ${ }^{25}$

\section{Maret 2019}

${ }^{25}$ Haiban Hadji, wawancara, Ketua Yayasan Masjid Besar Al-Falah,07 


\section{Strategi Kesopanan}

Pada teori kesopanan ini Brown dan Levinson menyatakan bahwa kesopanan merupakan nilai universal secara kultural. Setiap kebudayaan memiliki derajat yang berbeda untuk menjadi sopan, tetapi semua orang memiliki kebutuhan untuk dihargai dan dilindungi ${ }^{26}$. Dalam hal ini masjid al-Falah menggunakan strategi kesopanan dalam rangka menasehati jama'ah yang hadir ke masjid tersebut guna meningkatkan kualitas pemahaman jama'ah. Karena pada dasarnya manusia memiliki sifat pelupa dan khilaf sehingga aturan yang ada di masjid tersebut terkadang lupa untuk ditaati dan diikuti, Dengan hal inilah pengurus masjid menegur hal itu secara tidak secara langsung.

Proses menasehati berlangsung ketika akan memulai kajian, biasanya moderator atau pembawa acara akan mengingatkan kepada jama'ah secara umum agar tidak mengganggu keberlangsungan pada kegiatan kajian tersebut dengan membacakan peraturan-peraturan yang dapat mengganggu konsentrasi dalam kajian tersebut, biasanya para jama'ah akan dihimbau untuk tidak melanggar aturan yang ada, karena apabila aturan itu dilanggar khawatir akan mengganggu konsentrasi bagi jama'ah maupun para da'i yang sedang menyampaikan materi.

Aturan-aturan tersebut biasanya berisi, larangan untuk menonaktifkan alat elektronik seperti HP (band phone) karena itu akan membuat konsentrasi pecah dalam keberlangsungan kegiatan ta'lim tersebut, aturan berikutnya berupa anjuran bagi para ummahat yang memiliki anak agar bisa mengendalikan anaknya ketika kegiatan berlangsung karena dikhwatirkan jama'ah akan terganggu karena rengekan anak kecil, karena pada dasarnya anak kecil cenderung bosan terhadap apa yang ia lakukan apalagi harus duduk berjam-jam untuk mengikuti kegiatan ta'lim tersebut bersamanya dengan ibunya, dan masjid al- falahini memberikan solusi kepada para jama'ah yang memiliki anak kecil untuk duduk di luar masjid agar anak bisa leluasa bermain tanpa mengganggu jama'ah yang lainnya. Nasehat ini disampaikan kepada seluruh jam'ah ,hal

${ }^{26}$ Morissan,Teori Komunikasi,Bogor:Ghalia Indonesia,2013, Cet I, hal 110. 
ini dilakukan untuk melindungi wajah atau harga diri dari jama'ah tersebut agar dia tidak merasa malu atau rasa tidak enak lainnya ${ }^{27}$.

Dalam proses inilah jama'ah akan segera sadar akan kesalahannya sehingga langsung memperbaiki diri dan tidak mengulang kesalahan yang sama. Proses penyampaian secara khusus ini juga dilakukan agar semua jama'ah memiliki kesadaran secara menyeluruh sehingga ketika ada jama'ah yang melanggar sebuah peraturan maka akan diingatkan oleh jama'ah yang lain. Teori kesopanan inilah yang menjadi dasar atas keberlangsungan da'wah di masjid al- falahtersebut.

Masjid al-Falah ini juga membuka peluang bagi seluruh jama'ah yang ingin berkonsultasi terkait sebuah masalah khususnya dalam masalah yang ada dalam diri manusia (jiwa) seperti gangguan jin, sihir dan lain sebagainya. Masjid al- Falah mengundang tim yang ahli dalam bidang yang terkait guna, membantu jama'ah yang ingin berkonsultasi. Program ini disampaikan dengan menggunakan teori kesopanan karena berlangsung secara intensif serta secara khusus. Penyampaian pesan atau nasihat pada program ini berlangsung secara individu sehingga tidak banyak diketahui oleh orang banyak, artinya setiap orang yang memiliki masalah baik secara pribadi ataupun umum akan diceritakan kepada tim tersebut tanpa diketahui oleh banyak orang, hal ini dilakukan karena untuk menjaga perasaan jama'ah tersebut karena ada beberapa jama'ah yang merasa memiliki masalah akan tetapi malu untuk berkonsultasi, padahal sebenarnya butuh akan solusi dari masalah tersebut. Program ini diharapkan bisa membantu para jama'ah masjid al-Falah untuk bisa berkonsultasi dengan tim tersebut dan membantu memecahkan persoalan jama'ah khususnya dalam bidang ruqyah syar'iyyah.

Ketiga teori tersebut digunakan dalam strategi komunikasi pengurus masjid dalam menanamkan nilai-nilai keislaman kepada jama'ah, ketiga teori tersebut saling berksesinambungan antar satu dengan yang lainnya. Karena pada teori kepatuhan pada kegiatan ta'lim yang menghadirkan para da'i yang berkompeten akan menghasilkan pemahaman kepada jama'ah terhadap pesan yang di sampaikan da'I hal ini akan menimbulkan kepatuhan kepada jama'ah atas apa yang disampaikan oleh para da'i, jama'ah akan menerima pesan dengan baik dan menerapkannya dalam pribadi masing-masing dalam diri umat Islam sehingga proses saling

${ }^{27}$ Observasi, Februari 2019 
menasehatipun akan terjalin dengan baik sehingga proses penanaman nilainilai keislaman terhada[ jama'ah akan mudah terbentuk.

Kesimpulan Analisis Teori

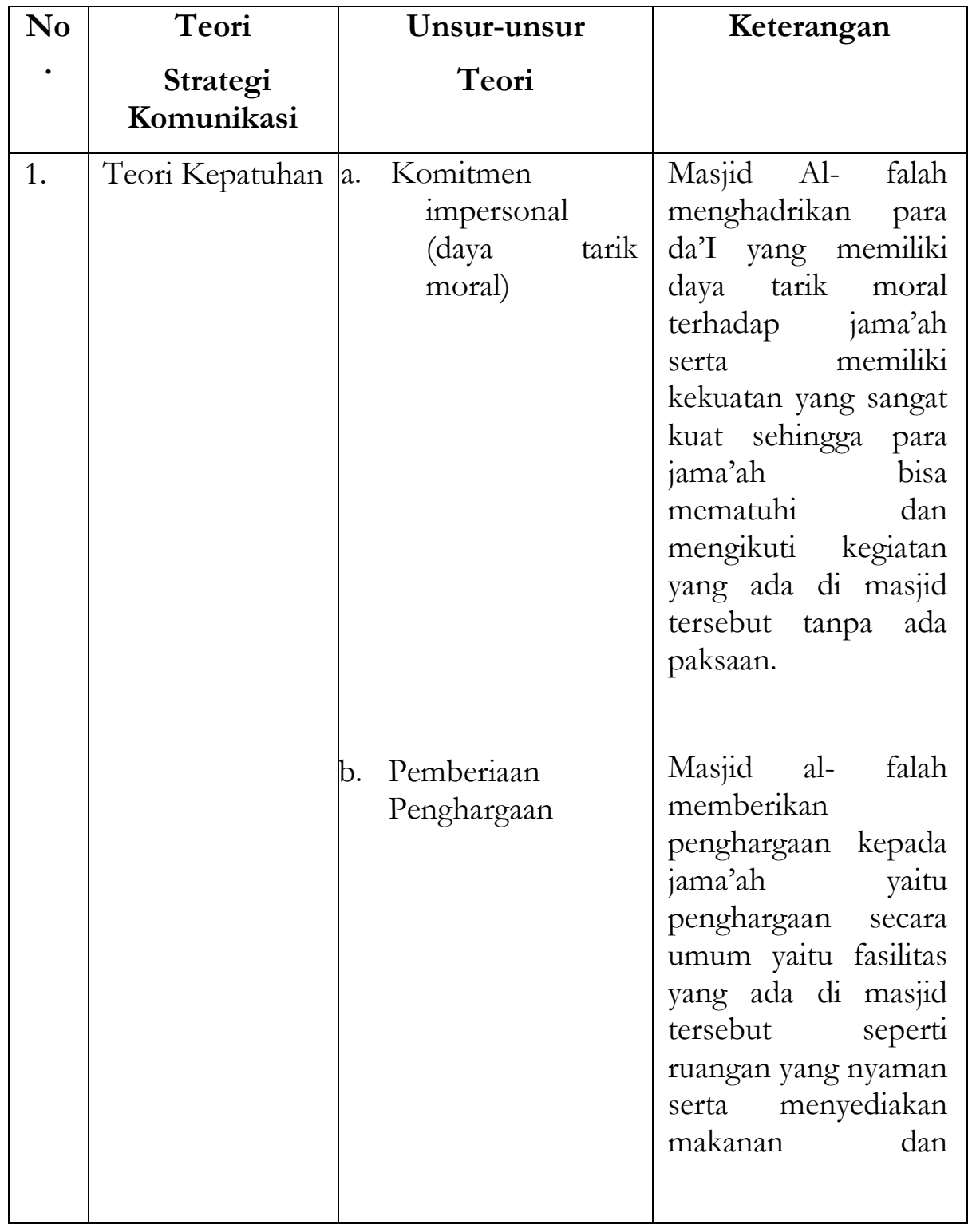




\begin{tabular}{|c|c|c|c|}
\hline & & $\begin{array}{l}\text { c. Menunjukan } \\
\text { Keahlian }\end{array}$ & 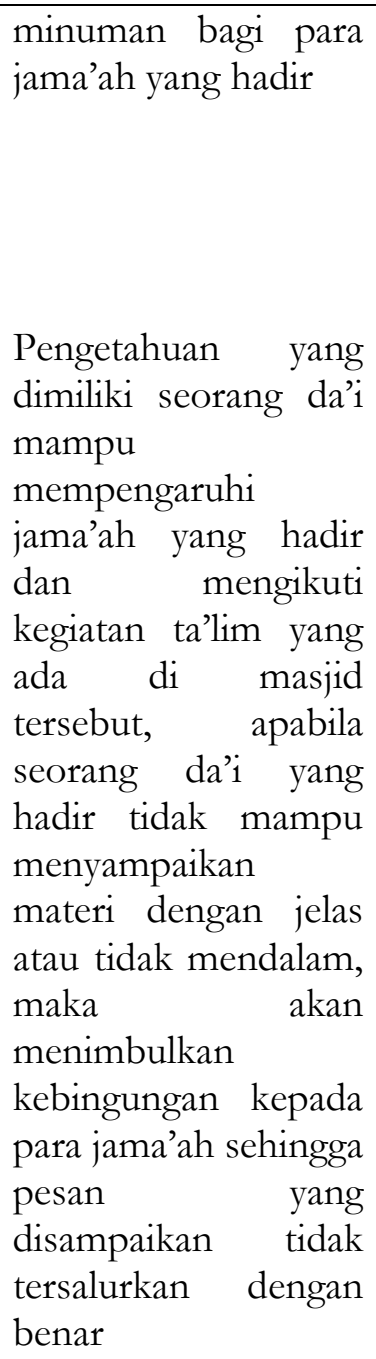 \\
\hline 2. & $\begin{array}{l}\text { Teori } \\
\text { Konstruktivisme }\end{array}$ & - & $\begin{array}{lr}\text { Jama'ah yang hadir di } \\
\text { masjid al- } & \text { falah } \\
\text { memiliki } & \text { latar } \\
\text { belakang } & \text { yang } \\
\text { berbeda dan berasal } \\
\text { dari daerah yang } \\
\text { berbeda pula, hal ini }\end{array}$ \\
\hline
\end{tabular}




\begin{tabular}{|c|c|c|c|}
\hline & & & \begin{tabular}{l}
\multicolumn{2}{l}{ menyebabkan } \\
keberagaman budaya \\
antar jama'ah di \\
masjid tersebut. \\
meskipun demikian \\
masjid al-Falah \\
memberikan peluang \\
kepada siapa saja baik \\
dari suku mana saja \\
untuk mengikuti \\
kegiatan yang ada di \\
masjid tersebut. yaitu \\
dengan cara \\
menghargai setiap \\
budaya yang dibawa \\
oleh jama'ah tersebut. \\
yang pada akhirnya \\
setiap jama'ah yang \\
hadir akan \\
mendapatkan kajian \\
yang sama. Dan dalam \\
hal inilah persamaan \\
tujuan ditanamkan.
\end{tabular} \\
\hline 3. & $\begin{array}{l}\text { Teori } \\
\text { Kesopanan }\end{array}$ & - & $\begin{array}{lr}\text { Masjid } & \text { al-Falah } \\
\text { memberikan } & \text { nasihat } \\
\text { kepada } & \text { jama'ah } \\
\text { melalui kegiatan ta'lim } \\
\text { dengan metode tanya } \\
\text { jawab rabadap } \\
\text { jama'ah. }\end{array}$ \\
\hline
\end{tabular}

Kegiatan ta'lim atau kajian yang ada di masjid al-Falah merupakan program unggulan yang ada di masjid tersebut. Para pengelola masjid dapat menjadikan program ini sebagai salah satu cara untuk memberikan pemahaman nilai-nilai keislaman kepada para jama'ah, kegiatan ta'lim yang ada di masjid tersebut hampir dilaksanakan setiap hari guna menunjang 
kebutuhan para jama'ah akan pengetahuan Islam. Kegiatan ta'lim pun sangat beragam ada yang khusus untuk anak-anak dengan cara penyajiannya yaitu dengan bercerita mengenai kisah-kisah para nabi sesuai dengan kebutuhan anak-anak, untuk remaja dengan cara penyajiannya yaitu mengadakan kegiatan ta'lim berupa sharing agar para remaja mampu terbuka dengan pemuda lain, dan untuk umum yang tentunya seluruh kalangan bisa mengikuti kegiatan tersebut.

Tidak hanya dilaksanakan secara langsung dimasjid saja, namun kegiatan ta'lim pun di syiarkan secara langsung melalui akun sosial media youtobe yang dapat diakses seluruh jama'ah yang terhubung dengan jaringan internet, hal ini memudahkan para jama'ah untuk bisa tetap mengikuti kajian meskipun tidak berada di masjid al-Falah secara langsung, juga memudahkan masyarakat agar bisa membuka kembali kajian-kajian yang telah berlangsung di masjid al-Falah dengan cara membuka youtobe. Begitupun di media sosial lain masjid al-Falah juga memilik akun instagram dan whatsapp guna memberikan informasi terhadap kegiatan yang akan dilaksanakan di masjid tersebut.

Daya tarik moral yang merupakan salah satu strategi yang digunakan masjid al-Falah untuk melangsungkan kegiatan da'wah melalui para da'i ialah salah satu keunggulan masjid ini dibandingkan dengan masjid lain, karena disini para da'i memiliki peran guna menerapkan nilai-nilai keislaman kepada jama'ah dengan kekuasaan atau cara yang dimiliki seorang da'i tersebut, karena semakin besar kekuasan seorang komunikator dalam hal ini adalah seorang da'i maka pesan akan tersampaikan dengan baik dan proses komunikasi dapat berjalan dengan lancar dan baik.

Masjid al-Falah menggunakan kekuatan para da'i untuk membantu para jama'ah menerima dan memahami Islam secara lebih mendalam, karena para da'i tersebut sudah memiliki tempat khusus dihati para jama'ah, sehingga tanpa iming-iming apapun jama'ah akan hadir dengan kerendahan hatri di masjid tersebut untuk memakmurkan masjid. Berawal dari inilah para jama'ah akan kembali ke masjid dan menghidupkan kembali fungsi masjid yang sebenarnya dan juga para jama'ah akan senang apabila menghadiri masjid.

Seluruh kegiatan yang ada di masjid tidak luput dari pergerakan para pengelola masjid. Para pengelola masjid terus bermusyawarah guna mengeratkan ukhuwah dan merancang langkah-langkah untuk 
melangsungkan kegiatan di masjid tersebut, hal inilah yang menjadikan seluruh kegiatan yang ada di masjid tersebut berjalan dengan lancar, pengelola masjid selalu menerima masukan dan saran dari para jama'ah guna meningkatkan kenyamanan masjid, tidak hanya mengenai kuantitas jamaah yang hadir dimasjid tersebut tetapi masjid al-Falah ini juga mementingkan kualitas para da’i dan kenyaman masjid.

Apabila jama'ah merasa nyaman dengan seluruh fasilitas yang diberikan kepada mereka maka akan mudah sekali tercapainya pemahaman nilai-nilai keislaman pada jama'ah tersebut, karena tidak ada lagi alasan untuk menolak apa yang telah diperintahkan oleh Allah dan Rasul melalui kegiatan ta'lim tersebut.

Karena Kepatuhan akan didapatkan apabila kerja sama antar pengelola masjid, da'I dan para jama'ah terjalin dengan baik sehingga proses menasehati akan mudah tersampaikan dan berjalan dengan baik.

Masjid al-Falah memanfaatkan seluruh fasilitas yang ada untuk memakmurkan masjid, seperti tema kajian yang menarik dan menghadirkan ustad yang memiliki daya tarik besar pada jama'ah, hal ini yang menjadikan pola utama keberhasilan da'wah yang dilakukan oleh masjid al-Falah dalam memakmurkan masjid.

\section{KESIMPULAN}

Berdasarkan hasil penelitian yang dilakukan oleh penulis dengan judul "Strategi Komunikasi Yayasan Besar Masjid al-Falah dalam Menanamkan Nilai-nilai Keislaman pada jama'ah, maka dapat ditarik kesimpulan sebagai berikut:

Secara Strategi kepatuhan Masjid Besar al-Falah memiliki potensi yang sangat besar dalam mensyiarkan da'wah, hal ini bisa dilihat dari kelebihan dan strategi yang digunakan oleh masjid tersebut dalam upaya untuk mengajak masyarakat memahami akan pentingnya sebuah masjid dalam pembinaan ummat. Hal ini berdasarkan strategi komunikasi yang digunakan yaitu strategi kepatuhan yang memiliki kekuatan besar seorang da'i yang dihadirkan oleh masjid tersebut sehingga dengan hal inilah da'wah akan mudah tersampaikan kepada jama'ah. Seorang da'i yang dihadirkan masjid tersebut memiliki daya tarik moral tersendiri di hati para jama'ah serta memiliki kemampuan yang ahli dalam bidangnya seperti dalam fiqih, 
aqidah, dan para da'i yang memiliki kemampuan dalam ilmu al-qur'an. Hal ini bertujuan agar jama'ah dapat langsung menerima ilmu dari ahlinya, dan ini menjadi prioritas utama yang dihadirkan masjid terhadap para jam'ah.

Berdasarkan strategi Konstruktivisme Semua kegiatan yang dilakukan di masjid al-Falah di klasifikasikan berdasarkan usia sehingga semua kalangan dapat mengikuti kegiatan tersebut seperti kajian remaja, anak-anak, sampai orangtua. Dan kegiatan tersebut disajikan dengan bentuk yang sederhana dengan penyampaian materi kegiatan yang mudah dipahami oleh jama'ah. Masjid ini mengutamakan fasilitas untuk kenyamanan para jama'ah yang ingin mengikuti kegiatan yang ada di masjid tersebut. Yayasan besar masjid al- Falah dalam perannya telah meningkatkan fungsi masjid yang tidak hanya terbatas sebagai tempat ibadah saja, masjid ini juga dijadikan sebagai tempat pendidikan, dan juga sentral kegiatan da'wah bagi masyarakat.

Berdasarkan strategi kepatuhan masjid al-Falah memberikan pelayanan khusus bagi para jama'ah untuk berkonsultasi permasalahan yang dihadapi dengan secara khusus (Ruqyah), yaitu dengan mengahdirkan team ruqyah syariyyah untuk membersamai para jama'ah yang memiliki keluhan dalam dirinya dengan cara khusus sehingga bisa melindungi para jama'ah dari rasa malu akan permasalahan yang dihadapinya.

\section{DAFTAR PUSTAKA}

\section{A. Buku}

,Metode Penelitian Kuantitafif, Kualitatif dan R\&d,Bandung :

Alfabeta cv, 2013

Prenada Media, 201

Teori Komunikasi Individu bingga Massa, Jakarta : Kencana

Metode Manajemen Penelitian,Bandung : CV Alfabeta, 2013

Abdul Qadir Jawas, Yazid bin, Syarah Aqidah Ablusunnah Wal

Jam'ah,Jakarta: Pustaka Imam Syafi'I,

Ajaj. Muhammad Al-Khatib, Ushul al-hadist, Jakarta: Gaya Media Pratama,2015

Al- Hasyimi ,Abdul Mun'im, Akblak Rasul menurut Bukbari dan Muslim, Depok: Gema Insani ,2009 
Al-Khatib, Muhammad 'Ajaj, Ushul al-hadist, Jakarta: Gaya Media Pratama, 2015

Al-Mubarakfuri, Syaikh Syaifurrahman, Ar-rahiq Al-Makbtum. Kelapa Dua Wetan-Ciracas-Jakarta Timur : Ummul Qura, 2012

Anshari ,Endang Syaifuddin,W awasan Islam, Jakarta:Gema Insani , 2004 Arifin, Anwar ,Strategi Komunikasi,Bandung : Armico 1984

Bungin, Burhan, Peneltian Kualitatif, Jakarta: PT Kharisma Putra Utama, 2017

Dzajuli, Ilmu Figh,Jakarta: Prenada Media Group, Cet ke-7, 2010

Gazalba, Sidi, Ilmu Filsafat dan Islam tentang manusia dan agama,Jakarta:Bulan Bintang 1978,

Hefni, Harjani, Komunikasi Islam Jakarta : Liliweri,Alo, Komunikasi Serba Ada Serba Bisa, Jakarta Prenada Media Group, 2015

Moch Fakhrurojhi, Manajemen Masjid, Bandung: Benang Merah Press, 2005

Moch Fakhrurojhi, A. Bachrudin Rifai Manajemen Masjid, Bandung: Benang Merah Press, 2005

Moloeng, Lexy J, Metedologi Penelitian Kualitatif, Bandung: PT. Remaja Rosdakarya, .2015.

Morissan, Psikologi Komunikasi, Bogor: Ghalia Indonesia, 2010

Mulyana, Dedy, Ilmu Komunikasi,Bandung: PT Remaja Rosdakarya, Cet XVII, 2013

Munawaroh, Fathimah Strategi Komunikasi Da'wah Yayasan Alkhansa dalam mengantisipasi Kristenisasi di wilayah BSD, Tanggerang Selatan, Skripsi, Jakarta STID Mohammad Natsir, 2016.

Muri, A Yusuf, Metode Penelitian, Jakarta: Kencana , 2007

Natsir, M , Fiqhud Da'wah , Bekasi Selatan: Sinar Media Abadi , 2017

Nazir, Mohammad, Metode Penelitian, Bogor: Ghalia Indonesia, 2005

Rifa', Bachrudin ,Manajemen Masjid, Benang Merah Press, Bandung, 2015 
Saifuddin Anshori, Endang Anshari, Wawasan Islam, Jakarta: Gema Insani, 2004

Sugiyono,Metode Peneletian kuantitatif, kualitatif dan R\&D,Bandung : CVAlfabeta, 2011

Sukmadinata, Syaudih Sukmadinata, Metode Penelitian Pendidikan, Bandung : PT.Remaja Rosdakarya, 2010.

Tim prodi KPI dan PMI STID Mohammad Natsir,Buku Panduan

Menyusun Skripsi,Bekasi : STID Mohammad Natsir Press, 2018

Tim Pustaka Phonex, Kamus Besar Bahasa Indonesia Edisi Baru, Jakarta: PT

Media Pustaka Phonex, 2009

Uchjana, Onong Effendy.,M.A., ilmu,teori, dan filasafat komunikasi,PT.

Citra Aditya Bakti : Bandung, 2003.

Usman, Husaini, Metodologi Penelitian Sosial, Jakarta : PT.Bumi Aksara, 2000

\section{B. Website}

Sistem Informasi Masjid,Website: http://simas.kemenag.go.id

www.Instagram.com/@alfalah bambuapus. 